\title{
Physicochemical Parameters of Surface Seawater in Malaysia Exclusive Economic Zones Off the Coast of Sarawak
}

\author{
FARAH AKMAL IDRUS* ${ }^{*}$, MELISSA DENNIS CHONG ${ }^{1}$, NUR SYAZWANI ABD \\ RAHIM $^{1}$, MASANIA MOHD BASRI ${ }^{1} \&$ JAMIL MUSEL $^{2}$
}

\author{
${ }^{1}$ Faculty of Resource Science and Technology, Universiti Malaysia Sarawak, 94300 Kota Samarahan, \\ Sarawak, Malaysia; ${ }^{2}$ Bintawa Fisheries Research Institute, Peti Surat 2243, Bintawa, Sarawak, Malaysia \\ *Corresponding author: aifarah@unimas.my
}

\begin{abstract}
Physicochemical characteristics of seawater play crucial role for productive marine ecosystem and fisheries activities. The limited information of Sarawak surface seawaters provide objective to determine the physicochemical characteristics in Malaysia Exclusive Economic Zone off the Coast of Sarawak. A total of 38 samples were collected using Van Dorn Waals Sampler and the physicochemical characteristics were measured using physicochemical parameter probes. Ranges for dissolved oxygen (DO) was 3.73-6.83 mg/l, temperature was $27.03-30.13^{\circ} \mathrm{C}$, pH was 7.63-7.82, salinity was $33.77-36.77 \mathrm{ppt}$, turbidity was $0.01-1.01 \mathrm{NTU}$, chlorophylla concentration was $0.01-4.52 \mathrm{mg} / \mathrm{l}$, nitrate was $0.01-0.08 \mathrm{mg} / \mathrm{l}$, nitrite was $0.001-0.012 \mathrm{mg} / 1$ and phosphate was $0.01-5.95 \mathrm{mg} / \mathrm{l}$. There was positive correlation between chlorophyll- $a$ and nutrients that indicated the biological uptake by biota (e.g. phytoplankton). In conclusion, the present study shows that the Malaysia Exclusive Economic Zone off the Coast of Sarawak had minimal pollution based on Malaysia Marine Water Quality Criteria. An update for physicochemical characteristics of surface seawaters in the coverage areas is required as future work.
\end{abstract}

Keywords: Physicochemical parameters, seawater, surface water, South China Sea

\section{INTRODUCTION}

The occurrence of advection associated with the planktons, biological scavenging, dilution of oceanic waters, food chain relationships and also the transport of nutrients and other particles via atmosphere and land into the water, is known to commonly happened in the surface seawater (Ho et al., 2009; Sundarambal et al., 2010). The productivity of phytoplankton in surface seawater is promoted by the sunlight exposure rates and buoyancy of seawater which is crucial as the base of food-chain (Iverson, 1990; Sigman \& Hain, 2012). The primary production from plankton and biomass may varies according to different places and nutrient availability. Nutrient limitation is differing in aquatic systems; both $\mathrm{N}$ and $\mathrm{P}$ are limited in marine environment (Redfield, 1958; Hecky \& Kilham, 1988; Wang et al., 2003). The productivity fluctuation in surface water is a result from the fluxes flow of nutrients that possibly originates from both natural and anthropogenic origins as well as changes of physicochemical water properties which can subsequently change the water quality. Therefore, it could also influence the composition and availability of aquatic organisms as well as affecting the natural process in ecosystem such as coral reef habitats and seagrass habitats that are susceptible to change in environmental conditions (Yap et al., 2011; Sigman \& Hain, 2012; Velsamy et al., 2013).

South China Sea (SCS) is a part of the Pacific Ocean as semi-enclosed marginal sea, which has been known as the most productive fishing zones in the world. This is due to diverse marine habitats, hence becoming the most frequent fisheries zones that are crucial for food security due to high demand despite facing overfishing, alteration or destruction (Morton \& Blackmore, 2001; Ali \& Katoh, 2014; Witter et al., 2015). For example, study by Teh and Teh (2014) showed the reconstructed data of fisheries catch in Malaysia EEZ from 1950 to 2010 indicated that Peninsular Malaysia obtained 58.4 million tonnes, Sarawak obtained 6.4 million tonnes and Sabah obtained 15.8 million tonnes. Such productive areas that have efficiency to sustain aquatic life are depending on the biomass of phytoplankton. The biomass growth of phytoplankton and diversity of marine species (Sigman \& Hain, 2012) are influenced by the 
water quality (i.e. physicochemical parameters) such as DO, temperature, salinity, $\mathrm{pH}$, turbidity, nutrients and other parameters which are also essential to determine the relationship with the components involved in the biogeochemical cycles as well as a crucial key to monitor the water quality (Tan et al., 2002; Shazili et al., 2006; Faragallah et al., 2009; Yap et al., 2011).

The present study sites were located at the South-western of South China Sea within the Malaysia Exclusive Economic Zones (EEZ) waters that covered the area of $160,000 \mathrm{~km}^{2}$ with depth of approximately $200 \mathrm{~m}$. In brief, EEZ is a zone regulated by the Law of the Zone in which the states have the rights to exploit and use the marine resources that had been prescribed by the United Nations Convention. There were numerous of studies regarding water quality and pollution status were conducted in West Malaysia, however the information on these matters in Malaysia EEZ are limited. Hence, the objective of this study was to investigate the physicochemical water characteristics such as dissolved oxygen (DO), temperature, salinity, turbidity, $\mathrm{pH}$, chlorophyll$a$, and macronutrients (nitrate, nitrite and phosphate) in the surface waters of Malaysia EEZ off the coast of Sarawak.

\section{MATERIALS AND METHODS}

There were 38 surface seawater $(\sim 3 \mathrm{~m})$ samples collected for physicochemical parameters analysis during the Malaysia EEZ Survey Project on board MV SEAFDEC2 from August to October 2015, between $2-6^{\circ} \mathrm{N}$ and $100-$ $113^{\circ} \mathrm{E}$ (Figure 1 and Table 1 ). The time and weather during sampling were highlighted as it could influence the measurement of physicochemical water properties.

The physicochemical parameters analysed insitu were salinity (ppt, refractometer Atago PAL-06S), $\mathrm{pH}$ ( $\mathrm{pH}$ meter Extech instrument, SPL 100), turbidity (NTU, turbidity meter Extech instrument, TN 100), temperature $\left({ }^{\circ} \mathrm{C}\right)$ and DO (mg/l, DO meter Extech instrument, SPL 150).

Concentrations of chlorophyll- $a$ (Chl- $a)$, were determined by using the method described by Aminot and Rey (2000), as summarized below. $500 \mathrm{ml}$ seawater sample at each station was filtered onto a Whatman GF/F $47 \mathrm{~mm}$ filter paper. After filtration, the filters were wrapped and placed in a properly labelled clean container. Then, the filters were immediately frozen at $-20^{\circ} \mathrm{C}$, prior to analysis in the

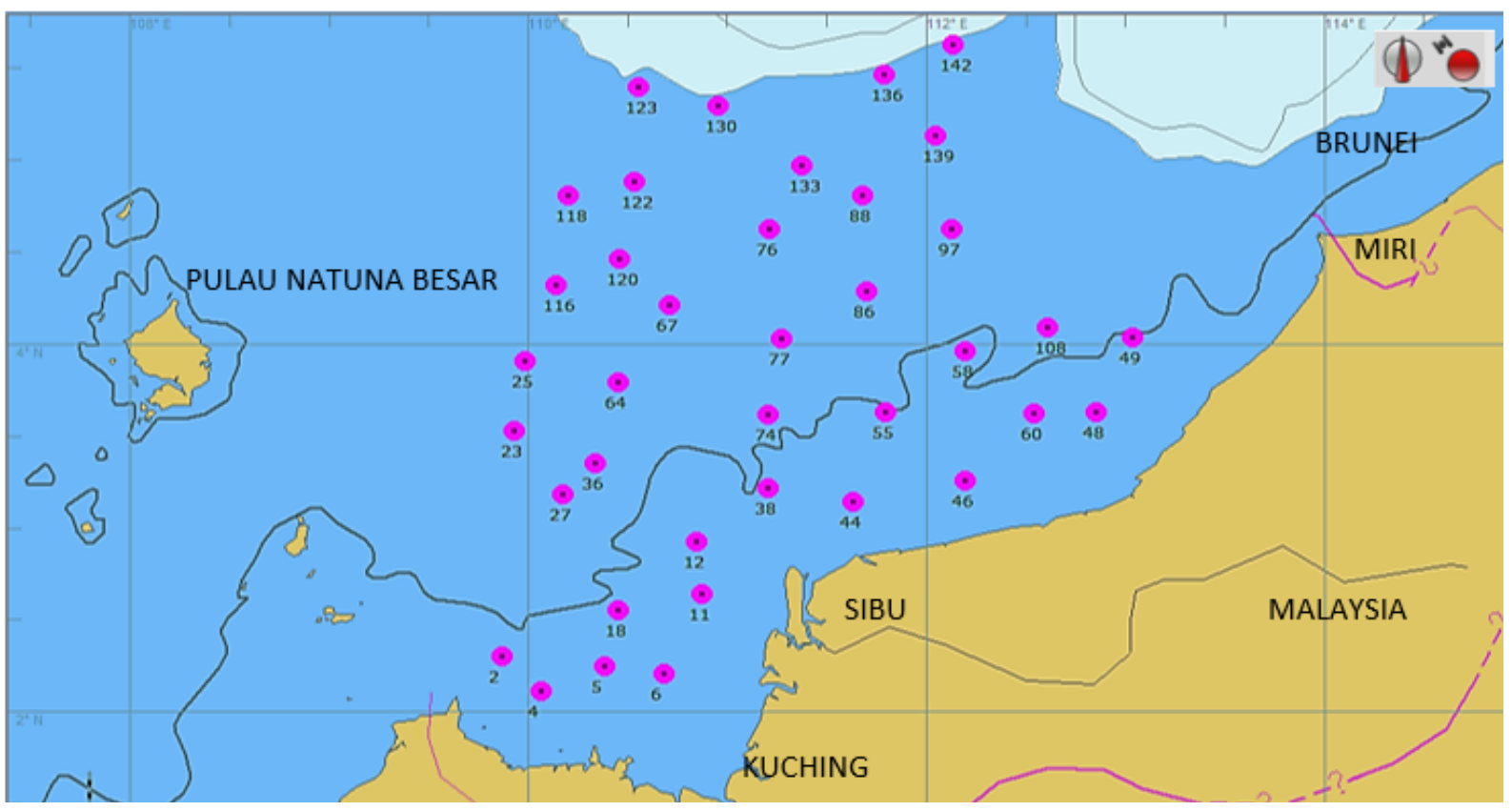

Figure 1. Location map shows 38 stations for collection of water samples. 
UNIMAS laboratory. In the laboratory, the filters were ground with mortar and pestle in a $10 \mathrm{ml}$ of $90 \%$ acetone under subdued light, then the solutions were added into the centrifuge tubes. The solutions were centrifuged (10 minutes, $3000 \mathrm{rpm}$ ) before analysed by using the spectrophotometer (Hach, DR 2800).

\section{Statistical Analysis}

All data were analysed using one-way analysis of variance ANOVA method with $95 \%$ confidence level among the physicochemical parameters and stations. The distribution of parameters was plotted by using the Ocean Data View software (Version 4.7.4).

Table 1. Sampling information of every stations in Sarawak waters.

\begin{tabular}{|c|c|c|c|c|}
\hline \multirow{2}{*}{ Stations } & \multirow[t]{2}{*}{ Date } & \multirow{2}{*}{ Time/ Weather } & \multicolumn{2}{|c|}{ Coordinate Position } \\
\hline & & & Latitude & Longitude \\
\hline 142 & $19 / 0815$ & 1241 - Rainy and cloudy & $5^{\circ} 37.39 \mathrm{~N}$ & $112^{\circ} 08.06 \mathrm{E}$ \\
\hline 139 & $20 / 08 / 15$ & 1210 - Cloudy & $5^{\circ} 07.59 \mathrm{~N}$ & $112^{\circ} 02.74 \mathrm{E}$ \\
\hline 97 & $21 / 08 / 15$ & 0530 - Cloudy & $4^{\circ} 37.22 \mathrm{~N}$ & $112^{\circ} 07.67 \mathrm{E}$ \\
\hline 108 & $22 / 08 / 15$ & 0525 - Cloudy & $4^{\circ} 05.25 \mathrm{~N}$ & $112^{\circ} 36.42 \mathrm{E}$ \\
\hline 49 & $22 / 08 / 15$ & 1247 - Cloudy & $4^{\circ} 01.97 \mathrm{~N}$ & $113^{\circ} 02.16 \mathrm{E}$ \\
\hline 48 & $23 / 08 / 15$ & 0850 - Cloudy & $3^{\circ} 37.49 \mathrm{~N}$ & $112^{\circ} 51.14 \mathrm{E}$ \\
\hline 50 & $26 / 08 / 15$ & 1217 - Cloudy and a bit rainy & $3^{\circ} 37.40 \mathrm{~N}$ & $112^{\circ} 32.70 \mathrm{E}$ \\
\hline 58 & $27 / 08 / 15$ & 0527 - Raining & $3^{\circ} 57.36 \mathrm{n}$ & $112^{\circ} 11.75 \mathrm{E}$ \\
\hline 86 & $28 / 08 / 15$ & 1040 - Partly cloudy & $4^{\circ} 17.14 \mathrm{~N}$ & $111^{\circ} 42.30 \mathrm{E}$ \\
\hline 88 & $29 / 08 / 15$ & 0750 - Sunny interval & $4^{\circ} 48.03 \mathrm{~N}$ & $111^{\circ} 40.95 \mathrm{E}$ \\
\hline 136 & $30 / 08 / 15$ & 0528 - Cloudy & $5^{\circ} 27.57 \mathrm{~N}$ & $111^{\circ} 47.58 \mathrm{E}$ \\
\hline 133 & $30 / 08 / 15$ & 1608 - Sunny interval & $4^{\circ} 57.58 \mathrm{~N}$ & $111^{\circ} 22.70 \mathrm{E}$ \\
\hline 55 & $1 / 09 / 15$ & 0935 - Sunny interval & $3^{\circ} 37.60 \mathrm{~N}$ & $111^{\circ} 47.82 \mathrm{E}$ \\
\hline 46 & $2 / 09 / 15$ & 0805 - Cloudy & $3^{\circ} 15.18 \mathrm{~N}$ & $112^{\circ} 11.87 \mathrm{E}$ \\
\hline 130 & $6 / 09 / 15$ & 1130 - Cloudy & $5^{\circ} 16.68 \mathrm{~N}$ & $110^{\circ} 57.33 \mathrm{E}$ \\
\hline 76 & $7 / 09 / 15$ & 0923 - Sunny interval & $4^{\circ} 31.16 \mathrm{~N}$ & $111^{\circ} 12.61 \mathrm{E}$ \\
\hline 67 & $8 / 09 / 15$ & 0525 - Cloudy, windy, bit haze & $4^{\circ} 12.38 \mathrm{~N}$ & $110^{\circ} 42.55 \mathrm{E}$ \\
\hline 77 & $8 / 09 / 15$ & 1610 - Cloudy, haze & $4^{\circ} 01.53 \mathrm{~N}$ & $111^{\circ} 16.67 \mathrm{E}$ \\
\hline 74 & $9 / 09 / 15$ & 1008 - Cloudy, haze & $3^{\circ} 37.11 \mathrm{~N}$ & $111^{\circ} 12.21 \mathrm{E}$ \\
\hline 44 & $10 / 09 / 15$ & 1224 - Cloudy, haze & $3^{\circ} 08.32 \mathrm{~N}$ & $111^{\circ} 38.24 \mathrm{E}$ \\
\hline 38 & $16 / 09 / 15$ & 1225 - Cloudy, haze & $3^{\circ} 13.05 \mathrm{~N}$ & $111^{\circ} 12.67 \mathrm{E}$ \\
\hline 120 & $17 / 09 / 15$ & 0745 - Cloudy, bit haze & $4^{\circ} 27.51 \mathrm{~N}$ & $110^{\circ} 27.62 \mathrm{E}$ \\
\hline 123 & $18 / 09 / 15$ & 0753 - Cloudy, bit haze & $5^{\circ} 23.69 \mathrm{~N}$ & $110^{\circ} 33.64 \mathrm{E}$ \\
\hline 118 & $19 / 09 / 15$ & 0920 - Cloudy & $4^{\circ} 48.04 \mathrm{~N}$ & $110^{\circ} 12.29 \mathrm{E}$ \\
\hline 122 & $19 / 09 / 15$ & 1230 - Cloudy & $4^{\circ} 52.39 \mathrm{~N}$ & $110^{\circ} 32.18 \mathrm{E}$ \\
\hline 116 & $19 / 09 / 15$ & 1722 - Cloudy & $4^{\circ} 19.45 \mathrm{~N}$ & $110^{\circ} 08.78 \mathrm{E}$ \\
\hline 64 & $19 / 09 / 15$ & 2140 - Partly cloudy & $3^{\circ} 47.30 \mathrm{~N}$ & $110^{\circ} 27.55 \mathrm{E}$ \\
\hline 12 & $20 / 09 / 15$ & 0530 - Cloudy & $2^{\circ} 52.22 \mathrm{~N}$ & $110^{\circ} 50.82 \mathrm{E}$ \\
\hline 11 & $20 / 09 / 15$ & 0815 - Cloudy & $2^{\circ} 38.40 \mathrm{~N}$ & $110^{\circ} 52.40 \mathrm{E}$ \\
\hline 18 & $20 / 09 / 15$ & 1110 - Partly cloudy & $2^{\circ} 32.85 \mathrm{~N}$ & $110^{\circ} 27.32 \mathrm{E}$ \\
\hline 5 & $20 / 09 / 15$ & 1342 - Partly cloudy & $2^{\circ} 14.57 \mathrm{~N}$ & $110^{\circ} 23.11 \mathrm{E}$ \\
\hline 6 & $20 / 09 / 15$ & 1612 - Partly cloudy & $2^{\circ} 12.29 \mathrm{~N}$ & $110^{\circ} 40.89 \mathrm{E}$ \\
\hline 2 & $2 / 10 / 15$ & 1458 - Cloudy & $2^{\circ} 17.94 \mathrm{~N}$ & $109^{\circ} 52.39 \mathrm{E}$ \\
\hline 27 & $3 / 10 / 15$ & 0658 - Cloudy & $3^{\circ} 10.81 \mathrm{~N}$ & $110^{\circ} 10.36 \mathrm{E}$ \\
\hline 36 & $3 / 10 / 15$ & 1242 - Sunny and a bit cloudy & $3^{\circ} 20.55 \mathrm{~N}$ & $110^{\circ} 20.33 \mathrm{E}$ \\
\hline 25 & $5 / 10 / 15$ & 0651 - Cloudy & $3^{\circ} 55.16 \mathrm{~N}$ & $109^{\circ} 59.85 \mathrm{E}$ \\
\hline 23 & $5 / 10 / 15$ & 1443 - Cloudy & $3^{\circ} 31.76 \mathrm{~N}$ & $109^{\circ} 55.83 \mathrm{E}$ \\
\hline 4 & $6 / 10 / 15$ & 1250 - Sunny & $2^{\circ} 06.36 \mathrm{~N}$ & $110^{\circ} 04.11 \mathrm{E}$ \\
\hline
\end{tabular}




\section{RESULTS AND DISCUSSION}

There was significant difference between all the physicochemical parameters among stations $(\mathrm{p}<0.05)$. The range for DO was $3.73-6.83$ $\mathrm{mg} / \mathrm{l}$ (Figure 2(a)). The range of $\mathrm{pH}$ value was $7.63-7.82$ (Figure 2(b)).

Marine organisms depend critically on the fate and behaviour of DO in water which in turn determines the severity of adverse impacts in an ecosystem (Best et al., 2007; Yap et al., 2011). In Malaysia EEZ surface seawaters off the coast of Sarawak, DO is under classification of Class 1, Class 2 and Class 3 (DOE, 2011). DO is higher at station 76 (with more than $5 \mathrm{mg} / \mathrm{l}$, Class 1) is considered as a Marine Preservation and Protected Areas. High DO in station 76 is possibly due to sampling period which the SST (sea surface temperature) was slowly increased and thus accelerates the photosynthetic production in releasing oxygen and organic matter. Other station that consist of approximately $4 \mathrm{mg} / 1$ to $5 \mathrm{mg} / 1$ are categorized in Class 2 in which the areas are mainly composed of marine life such as coral reefs, fisheries activity, recreational or mariculture activity. DO in less than $4 \mathrm{mg} / 1$ such as at station 18 is categorized in Class 3 in which the areas are located near the ports, oil and gas fields. Station 18 has low DO compared to other stations mainly due to situated near the Kuching ports with busy transportation of boats and ships and possible be affected by the temperature and salinity factors in surrounding. The increase of temperature due to the sun radiation which increases the salinity due to high evaporation rates attributed to low DO in surface seawater (Best et al., 2007; Faragallah et al., 2009; Patil et al., 2012). However, there is no correlation between DO with temperature and salinity in this study. Other factors that possibly influenced the DO was the biological activity such as oxygen production rates during respiration and photosynthetic process of planktons, decomposition process and nitrification process (Best et al., 2007; Faragallah et al., 2009; Yap et al., 2011; Patil et al., 2012). Oil spills and wastes from sea vessels possibly have minimized the exposure of sunlight penetrating into the surface seawater could affect the rate of photosynthetic process of planktons and increased the decomposition rate, and hence lower the DO (Yap et al., 2011). The $\mathrm{pH}$ shown in station $86(\mathrm{pH}=7.82)$ and $123(\mathrm{pH}$ $=7.79$ ) were higher compared to the $\mathrm{pH}$ in other stations suggested possible reduced rates of biological activity in surface water causing in low DO (Yap et al., 2011; Patil et al., 2012; Velsamy et al., 2013). Moreover, station 123 has been encountered typhoon from Vietnam which brought by prevailing southwest wind that elevated the wave storm up to approximately $6 \mathrm{~m}$ which also increased the water mixing in that area. According to the Fakaruddin et al. (2015), the period of tropical typhoon was active in August to September which experience the impact and changes of wind direction. $\mathrm{pH}$ in station $142(\mathrm{pH}=7.64)$ that has the lowest value compared to other station was possibly due to the raining weather before the sampling period. The $\mathrm{pH}$ of the rain
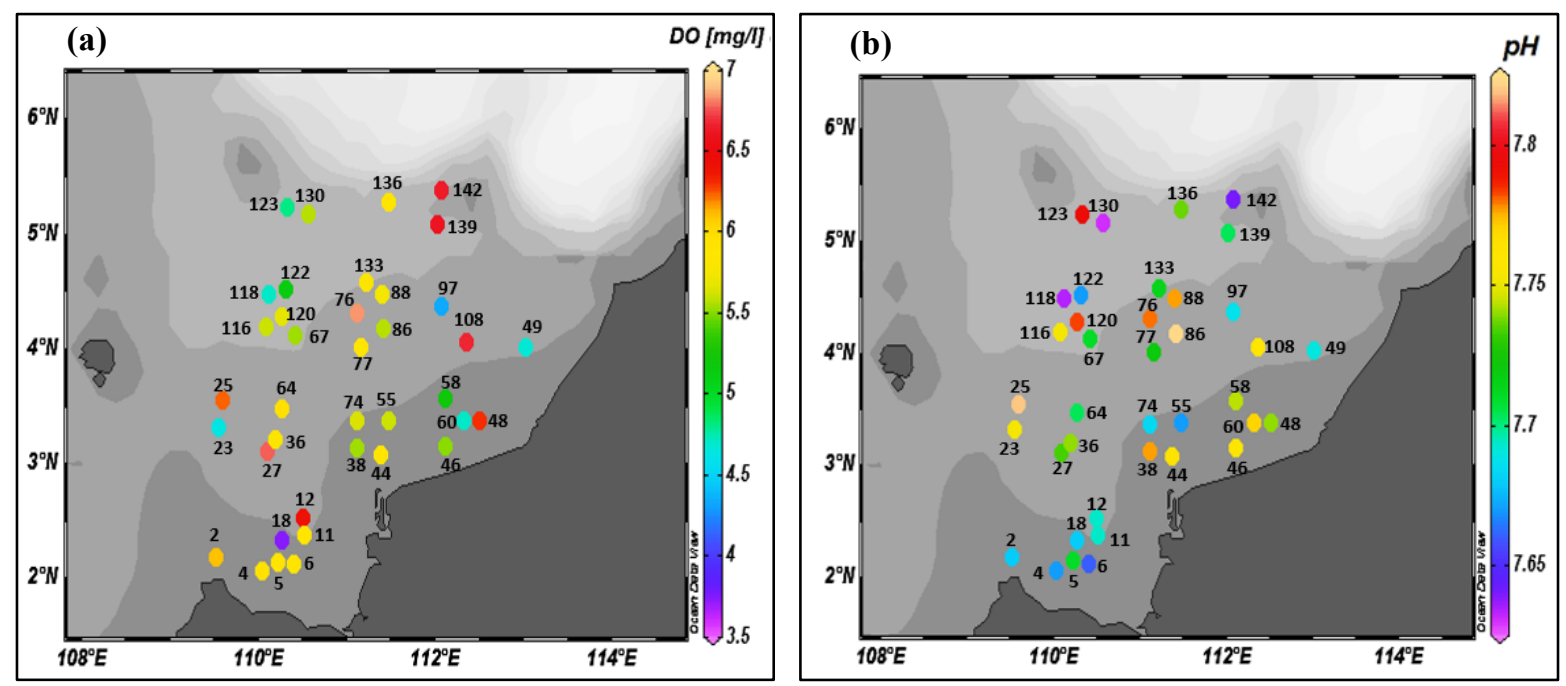

Figure 2. Concentration of DO (mg/l) (a) and pH (b) in Malaysia EEZ off the coast of Sarawak. 
was approximately $\mathrm{pH} 6$, thus influenced the chemical composition of carbonate and bicarbonate ions in seawater (Faragallah et al., 2009; Yap et al., 2011; Patil et al., 2012).

The range for sea surface temperature (SST) was $27.03-30.13^{\circ} \mathrm{C}$ (Figure 3(a)). The range values of SSS (sea surface salinity) were 33.77 -35.80 ppt (Figure 3(b)).

There was a narrow variation in SST with approximately $\pm 3^{\circ} \mathrm{C}$ and relatively isotherms due to situated in tropical waters (Tan et al., 2002; Ibrahim \& Yanagi, 2006; Sigman \& Hain, 2012). Other factors that could influence the SST were between the external and internal environmental factors such as exposure rates to solar radiation, rate of chemical reactions, climate, storm waves, monsoon seasons and haze (Tan et al., 2002; (Ibrahim \& Yanagi, 2006; Faragallah et al., 2009; Sundarambal et al., 2010; Patil et al., 2012; Velsamy et al., 2013). Low SST was due to the sampling period and whether shown in station 142. The pattern of SST was slightly opposite to the pattern of SSS. SST was found to be higher at the nearshore possibly due to the weather or wastewater discharged from the industries whereas SSS was found to be lower at nearshore zone due to freshwater influx. Low SSS in the wet (monsoon) season but high in dry season due to the amount of rainfall, the rate of evaporation and the recede and flow of water from neritic waters (Velsamy et al., 2013). Comparing the SST and SST values among the stations, low SSS with high SST compared to other stations in station 46

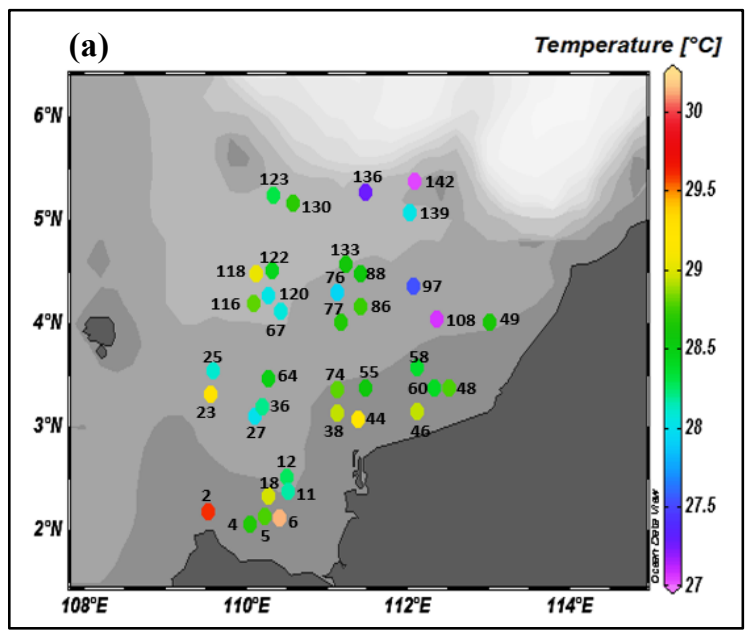

$\left(28.93^{\circ} \mathrm{C}, 33.77 \mathrm{ppt}\right)$ whereas high SSS and low SST in station $142\left(35.80 \mathrm{ppt}, 27.03^{\circ} \mathrm{C}\right)$ were possibly due to the different types of water masses. The water mass in surface seawater was categorized as Open Sea Water (OSW) and Continental Shelf Water (CSW) types, as defined and clarified by Arsad and Akhir (2013) (Table 2). Salinity was higher in Sarawak waters and OSW was commonly presence in this location between $2-5^{\circ} \mathrm{N}$ and $109-112^{\circ} \mathrm{E}$ (Arsad \& Akhir, 2013). Since the common weather in Sarawak waters is humid, the rate of evaporation is slightly increased during the dry season due to high temperature, thus influenced SSS (Morton \& Blackmore, 2001; Ibrahim \& Yanagi, 2006; Asrad \& Akhir, 2013; Velsamy et al., 2013).

The range value for turbidity was within the range of $0.01-1.01$ NTU (Figure 4(a)). The range for the concentration of chlorophyll- $a$ was $0.01-4.52 \mu \mathrm{g} / 1$ (Figure 4(b)).

Materials that caused the water to be turbid are wastes originate from the ships or transported from the land, organic matters, microscopic microorganisms, planktons, inorganic matters or even sediment (Lawler, 2004; Yap et al., 2011). The concentration of chlorophyll- $a$ is the important indicator to determine the biomass and growth of phytoplankton. It was indicated that long exposure of solar radiation from the sun could attributed in low concentration in chlorophyll- $a$ due to pigments degradation (Tan et al., 2002). This can be shown in station $6(0.01 \mu \mathrm{g} / \mathrm{l})$ due to sampling period with high SST $\left(>30^{\circ} \mathrm{C}\right)$ that influenced the photosynthetic activity due

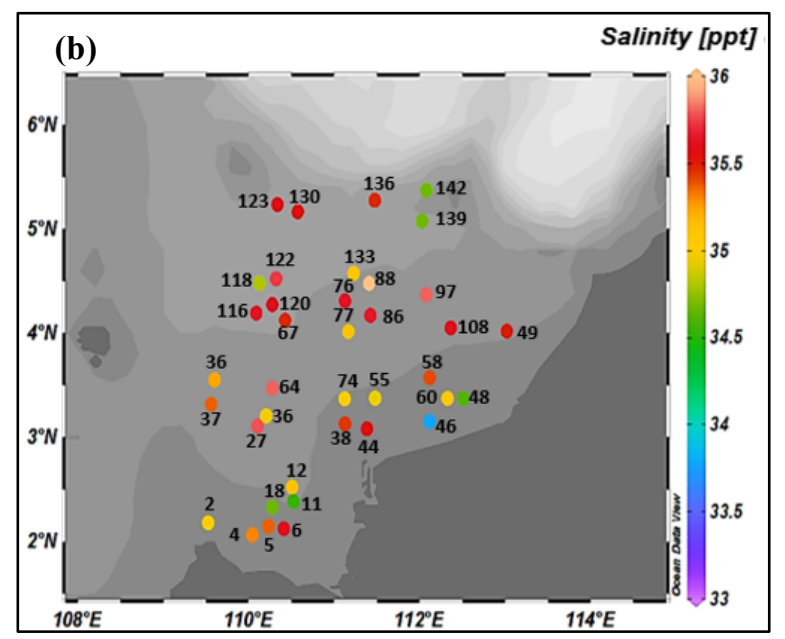

Figure 3. Sea surface temperature $\left({ }^{\circ} \mathrm{C}\right)(\mathrm{a})$ and salinity (ppt) (b) in Malaysia EEZ off the coast of Sarawak. 
Table 2. Comparison of salinity and temperature in surface water mass characteristics.

\begin{tabular}{|c|c|c|c|c|}
\hline \multicolumn{2}{|c|}{ Present study } & \multicolumn{2}{|c|}{ Arsad and Akhir (2013) } & \multirow{2}{*}{ Category } \\
\hline Salinity & Temperature & Salinity & Temperature & \\
\hline $33.8-36.8 \mathrm{ppt}$ & $27.0-30.1^{\circ} \mathrm{C}$ & $27.0-33.5 \mathrm{ppt}$ & $29-31^{\circ} \mathrm{C}$ & CSW \\
\hline & & $32.5-34.0 \mathrm{ppt}$ & $25-29^{\circ} \mathrm{C}$ & OSW \\
\hline
\end{tabular}
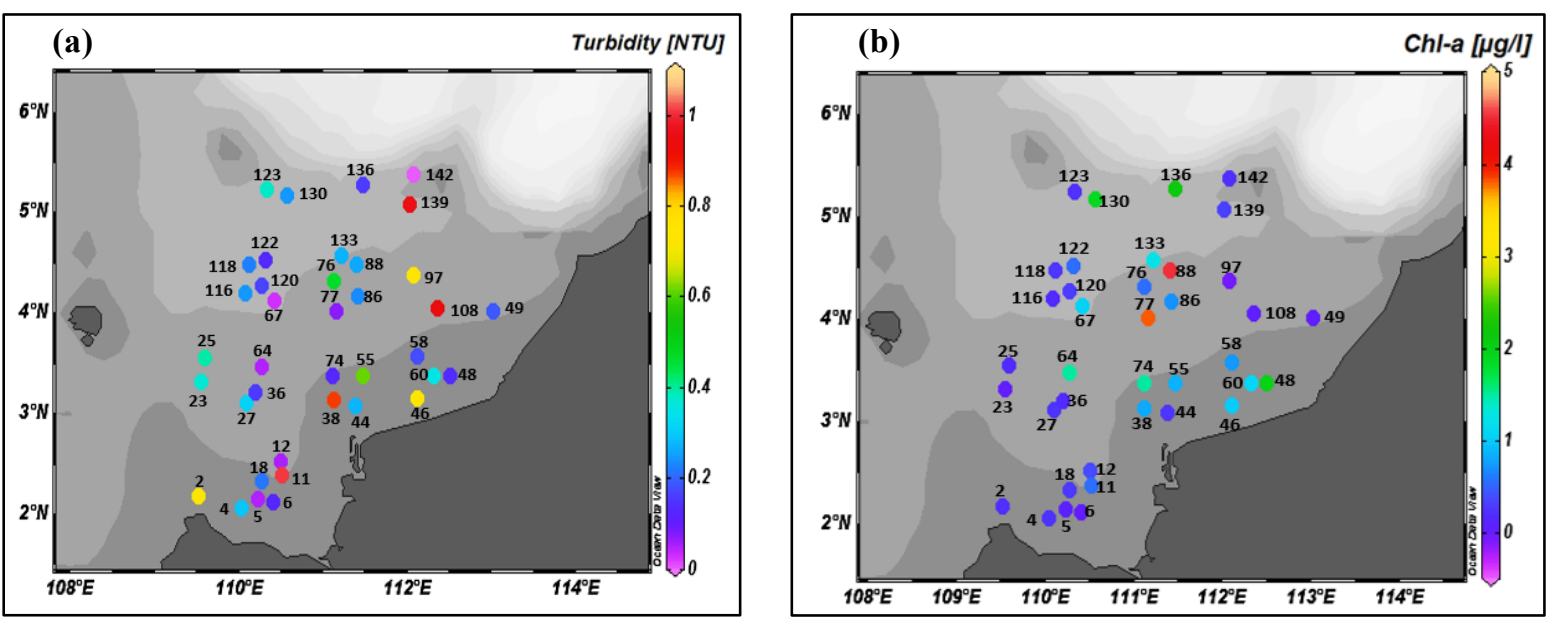

Figure 4. Concentration of turbidity (NTU) (a) and chlorophyll-a ( $\mu \mathrm{g} / \mathrm{l})$ (b) in Malaysia EEZ off the coast of Sarawak.

to more radiant energy from the sunlight and hence might affected the oxygen production $(\sim 5 \mathrm{mg} / \mathrm{l})$. Station 97 has low chlorophyll-a concentration (below $0 \mu \mathrm{g} / 1$ - below detection limit of the instrument) due to low macronutrients concentration (e.g. nitrate: 0.02 $\mathrm{mg} / \mathrm{l}$, phosphate: $1.68 \mathrm{mg} / \mathrm{l}$ ) resulting lower oxygen production. Station 88 has the highest chlorophyll- $a$ concentration among the stations

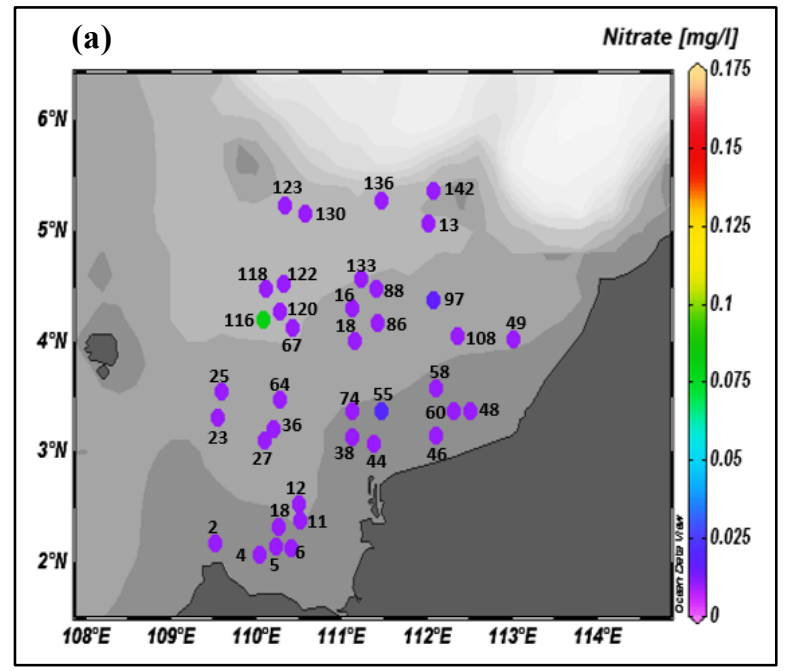

due to nutrient availability to support the phytoplankton at that area which was consistent with the low concentration of macronutrient (Faragallah et al., 2009).

The range of nitrate concentration was 0.01 $0.08 \mathrm{mg} / \mathrm{l}$ (Figure 5(a)). The range value for nitrite was $0.00-0.01 \mathrm{mg} / 1$ (Figure 5(b)). The range values for phosphate were between 0.01 $5.95 \mathrm{mg} / 1$ (Figure 6).

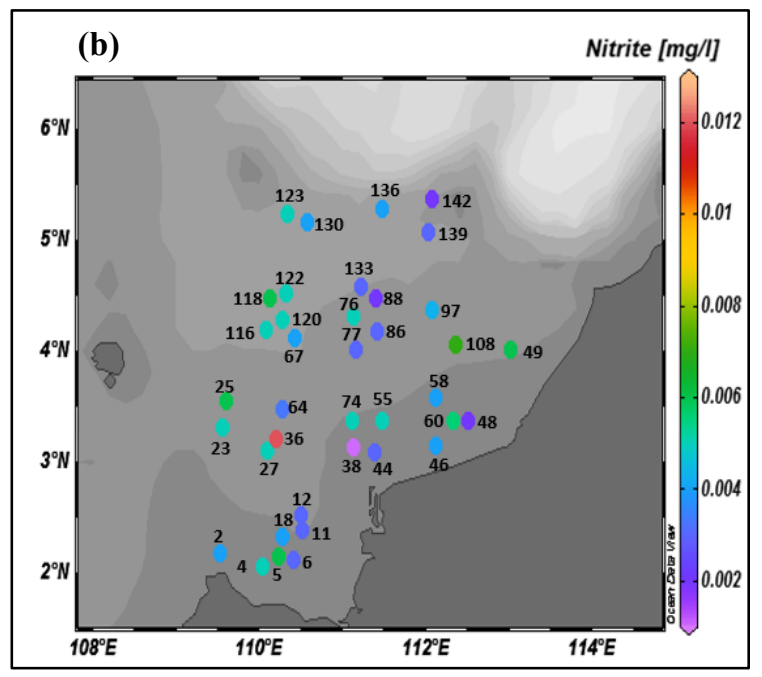

Figure 5. Concentration of nitrate $(\mathrm{mg} / \mathrm{l})(\mathrm{a})$ and nitrite $(\mathrm{mg} / \mathrm{l})(\mathrm{b})$ in Malaysia EEZ off the coast of Sarawak. 


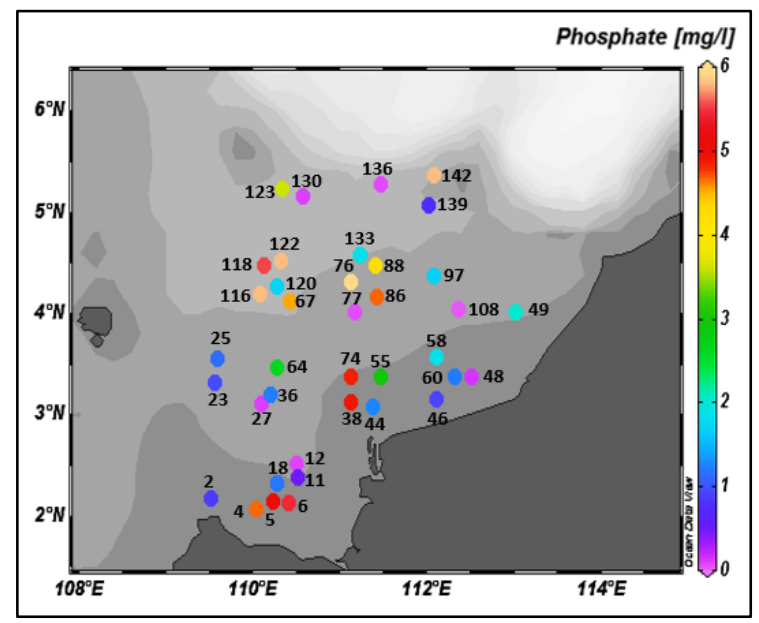

Figure 6. Concentration of phosphate $(\mathrm{mg} / \mathrm{l})$ in Malaysia EEZ off the coast of Sarawak.

Nitrite is the unstable and significant intermediate involved in the nitrogen-fixation and possibly increased from the denitrification process (Codispoti \& Christensen, 1985; Best et $a l ., 2007)$. The value of nitrite in this study is categorized in Class 2 and E (DOE, 2011). Both nitrate and nitrite are inorganic form of $\mathrm{N}$ in which is one of the essential elements contributing in the growth of phytoplankton and contribute in nitrification process. High concentration of nitrate in station 116 might due to the decomposition of organic matter such as floating of rotten woods and wastes from ships observed at that location. According to Faragallah et al. (2009), the concentration of nitrogen can be increasing attributed from the decomposition of organic matter. Relatively low concentration of total nitrogen, TN $\left(\mathrm{NO}_{3}, \mathrm{NO}_{2}\right)$ in Sarawak waters probably indicated an oligotrophic marine environment (low- nutrient - high - oxygen environment) which the nutrient is the limiting factor for phytoplankton, thus the concentration of chlorophyll- $a$ was relatively low (Behrenfeld $e t$ al., 2006).

The highest $\mathrm{P}$ concentration in station 76 followed by stations $142,74,38,118,122,116$, 5 and 6 were possibly due to the atmospheric inputs such as dry (dust) and wet (rain) depositions (Faragallah et al., 2009; Schlosser et al., 2014). Furthermore, haze was observed covering the atmosphere during the sampling period of these sites. Hazy weather is a significant anthropogenic source of nutrients inputs into the surface seawater as mainly the particles for dry deposition is in dissolved forms (Sundarambal et al., 2010). The haze state in Sarawak was due to the forest fires from Kalimantan and brought to Malaysia and other neighbouring countries via prevailing southeasterly winds from the south-west monsoon (ASEAN, 2015; Department of Environment, 2015). This is coincident with the high $P$ concentration in Sarawak EEZ waters. The P values that was less than $1 \mathrm{mg} / \mathrm{l}$ was categorized under Class 1, 2, 3 and $\mathrm{E}$ whereas more than $1 \mathrm{mg} / 1$ was mainly due to atmospheric inputs.

Table 3 showed the comparison between the values of water parameters obtained in present study and Malaysia Marine Water Quality Criteria and Standard (MMWQS) for the determination and categorization of the range of physicochemical water parameters. Most of the parameters were categorised in Class 2, 3 and E.

High concentration of chlorophyll- $a$ (4.52 \pm $0.05 \mathrm{mg} / \mathrm{l})$ with the low concentration of $\mathrm{TN}$ $(0.01 \pm 0.00 \mathrm{mg} / \mathrm{l})$ was shown in station 88 , whereas high concentration of chlorophyll- $a$ $(3.80 \pm 0.00 \mathrm{mg} / \mathrm{l})$ with low concentration of total phosphate (TP) $(0.04 \pm 0.00 \mathrm{mg} / \mathrm{l})$ was shown at station 77. Furthermore, high concentration of TN $(0.09 \pm 0.04 \mathrm{mg} / \mathrm{l})$ with considerable low concentration of chlorophyll- $a$ $(0.16 \pm 0.01 \mathrm{mg} / \mathrm{l})$ was shown in station 116 , whereas high concentration of TP $(5.82 \pm 0.01$ $\mathrm{mg} / \mathrm{l})$ with low concentration of chlorophyll- $a$ $(0.21 \pm 0.00 \mathrm{mg} / \mathrm{l})$ was shown at station 142 . These results showed that the concentration of chlorophyll- $a$ increased with the decreased concentration of macronutrient in which indicated as negative correlation between chlorophyll- $a$ and macronutrients (Total Nitrogen (TN): $r=-0.17$ and Total Phosphate (TP): $r=-0.12$ ). This refer to rapid utilization of TN and TP by phytoplankton or removal by suspended solids.

The chlorophyll- $a$ tend to be high at the peak SST in which exposed to sunlight during sampling or the availability of nutrient for photosynthesis that can be shown in station 88 . Moreover, the concentration of nitrate in the Pacific Ocean was quite high (up to $\sim 0.03 \mathrm{mg} / \mathrm{l}$ ) and the concentration relatively low towards the west-side of SCS indicated that high-nitratehigh-biomass zone tend to be at low latitude (Behrenfeld et al., 2006; Sigman \& Hain, 2012). At station 142, 76, 74, 18, 2 and 23, P 
Table 3. Comparison of value of physicochemical parameter between present study and Malaysia Marine Water Quality Criteria and Standard (MMWQS). S.D: standard deviation (adapted from DOE, 2011).

\begin{tabular}{|c|c|c|c|}
\hline \multirow{2}{*}{$\begin{array}{c}\text { Physicochemical } \\
\text { parameters }\end{array}$} & \multicolumn{2}{|c|}{ Present study } & \multirow{2}{*}{ MMWQS } \\
\hline & High value \pm S.D & Low value \pm S.D & \\
\hline $\mathrm{DO}(\mathrm{mg} / \mathrm{l})$ & $6.83 \pm 0.06$ & $3.73 \pm 0.06$ & $\begin{array}{c}>80 \% \text { saturation (Class 1), } 5 \text { (Class 2), } \\
3 \text { (Class } 3), 4 \text { (Class E) }\end{array}$ \\
\hline $\mathrm{pH}$ & $7.82 \pm 0.01$ & $7.63 \pm 0.01$ & - \\
\hline Temperature $\left({ }^{\circ} \mathrm{C}\right)$ & $30.13 \pm 0.06$ & $27.03 \pm 0.67$ & $\begin{array}{c}\leq 2^{\circ} \mathrm{C} \text { increase over maximum ambient } \\
(\text { Class } 1,2,3, \mathrm{E})\end{array}$ \\
\hline Salinity (ppt) & $36.77 \pm 0.06$ & $33.77 \pm 0.15$ & - \\
\hline Turbidity (NTU) & $1.01 \pm 0.10$ & $0.01 \pm 0.01$ & - \\
\hline Chlorophyll- $a$ (mg/l) & $4.52 \pm 0.05$ & $0.01 \pm 0.01$ & - \\
\hline Nitrate (mg/l) & $0.08 \pm 0.01$ & $<0.025$ & 0.06 (Class 2 and E), 1 (Class 3$)$ \\
\hline Nitrite (mg/l) & $0.01 \pm 0.01$ & Below Detection Limit & 0.055 (Class 2 and E), 1 (Class 3) \\
\hline Phosphate (mg/l) & $5.95 \pm 0.02$ & $0.01 \pm 0.01$ & $\begin{array}{c}0.005 \text { (Class 1), } 0.075 \text { (Class } 2 \text { and E), } \\
0.67 \text { (Class 3) }\end{array}$ \\
\hline
\end{tabular}

Notes: Class 1 - Preservation, Marine Protected areas, Marine Parks; Class 2 - Marine Life, Fisheries, Coral Reefs, Recreational and Mariculture; Class 3 - Ports, Oil and Gas Fields; Class E - Mangroves Estuarine and River-mouth Water.

concentrations were high due to less scavenging and more atmospheric inputs such as haze or rain (Faragallah et al., 2009; Sundarambal et al., 2010; Schlosser et al., 2014).

The nutrients uptake by the plankton generally is $16: 1$ of the $\mathrm{N}: \mathrm{P}$ ratio (Redfield, 1958). In comparison between $N$ and $P$ concentrations in Sarawak waters, $N$ have low concentration compared to $\mathrm{P}$ which suggested that Sarawak waters are mainly $\mathrm{N}$ deficiency (Hecky \& Kilham, 1988; Wang et al., 2003). Generally, the seawater in offshore zones tends to have lower concentration of nutrient due to the less exposure from the anthropogenic sources from terrestrial areas (Ho et al., 2009; Mayouf, 2013).

\section{CONCLUSION}

The range of physicochemical parameters such as DO, temperature, nitrate, nitrite and phosphate were within the range of MMWQS. The concentrations of macronutrients ( $\mathrm{N}$ and $\mathrm{P}$ ) were considerably low in the surface seawater of Malaysia EEZ off the coast of Sarawak due to less contact of human activities and actively involved in the biological activity. The fluctuation concentration of physicochemical parameters in Malaysia EEZ off the coast of Sarawak was mainly influenced by the anthropogenic origins, haze, strong current and monsoon seasons. The present study indicated that the Malaysia EEZ off the coast of Sarawak possibly had minimal pollution impact to the water quality and this study can be used to monitor the marine water quality in order to maintain the aquatic ecosystem and resources. However, limited portable instruments used during sampling due to unstable condition in the sea as well as analysis for other physicochemical parameters and covered more sampling areas should be considered for the next sampling in Malaysia EEZ off the coast of Sarawak for further studies.

\section{ACKNOWLEDGEMENTS}

This study was funded by the Small Scheme Grant F017 (S145)/1175/2014(10). The authors would like to acknowledge the Fisheries Research Institute (FRI), Fisheries Department Malaysia and MV SEAFDEC 2 for aiding and provide facilities throughout the research study. Appreciation also goes to all members in the Department of Aquatic Science for helping the sample collection.

\section{REFERENCES}

Ali, M. \& Katoh, M. (2014). Tagging program for economically important small pelagic species in the South China Sea and the Andaman Sea regional project terminal report. Southeast Asian Fisheries Development Center. SEAFDEC/MF $\mathrm{RDMD} / \mathrm{SP} / 27$.

Aminot, A. \& Rey, F. (2000). Standard procedure for the determination of chlorophyll-a by spectroscopic methods. Copenhagen, Denmark: ICES Techniques in Marine Environmental Sciences. Pp 1-16.

Arsad, S. \& Akhir, M.F. (2013). The characteristics 
and origin of water masses along the Sabah coast. International Journal, 1(1): 2311-2484.

ASEAN Specialised Meteorological Centre (2015). Monthly weather and gaze review: update of regional weather and smoke haze for October 2015. http://asmc.asean.org/update-of-regionalweather-and-smoke-haze-for-october-2015/. Downloaded on 30 December 2015.

Behrenfeld, M.J., Worthington, K., Sherrel, R.M., Chavez, F.P., Strutton, P., McPhaden, M. \& Shea, D.M. (2006). Controls on tropical Pacific Ocean productivity revealed through nutrient stress diagnostics. Nature, 442: 1025-1028.

Best, M.A., Wither, A.W. \& Coates, S. (2007). Dissolved oxygen as a physico-chemical supporting element in the Water Framework Directive. Marine Pollution Bulletin, 55(1): 5364.

Codispoti, L.A. \& Christensen, J.P. (1985). Nitrification, denitrification and nitrous oxide cycling in the eastern tropical South Pacific Ocean. Marine Chemistry, 16: 277-300.

Department of Environment (2011). Malaysia Marine Water Quality Criteria and Standard. https://www.doe.gov.my/portalv1/en/infoumum/piawaian-dan-kriteria-kualiti-air-marinmalaysia/301. Assessed on 6 February 2017.

Department of Environment, Ministry of Natural Resources and Environment, Malaysia (2015). http://www.doe.gov.my/. Assessed on 30 December 2015.

Fakaruddin, F.J., Saleh, F.Z., Yik, D.J., Adam, M.K. M., Sang, Y.W., Chang, N.K., Yunus, F. \& Abdullah, M.H. (2015). Technical Note No. 4/2015: Weather analysis from July until October 2015. Malaysian Meteorological Department. Ministry of Science, Technology and Innovation (MOSTI).

http://www.met.gov.my/web/metmalaysia/public ations/technicalpaper/fullpapers/document/44762 /n04_2015.pdf. Downloaded on 15 August 2016.

Faragallah, H.M., Askar, A.I., Okbah, M.A. \& Moustafa, H.M. (2009). Physico-chemical characteristics of the open Mediterranean Sea water about $60 \mathrm{~km}$ from Dametta harbour, Egypt. Journal of Ecology and the Natural Environment, 1(5): 106-119.

Hach Company (2007). DR 2800 Spectrophotometer procedures manual. Second Edition. USA: Loveland, CO.

Hecky, R.E. \& Kilham, P. (1988). Nutrient limitation of phytoplankton in freshwater and marine environments: a review of recent evidence on the effects of enrichment. American Society of Limnology and Oceanography, 33(4):
$762-822$.

Ho, T.Y., You, C.F., Chou, W.C., Pal, S.C., Wen, L. S. \& Sheu, D.D. (2009). Cadmium and phosphate cycling in the water column of the South China Sea: the roles of biotic and abiotic particles. Marine Chemistry, 115: 125-133.

Ibrahim, Z.Z. \& Yanagi, T. (2006). The influence of the Andaman Sea and the South China Sea on water mass in the Malacca Strait. La mer, 44: 3342.

Iverson, R.L. (1990). Control of marine fish production. Limology and Oceanography, 35(7): 1593-1604.

Lawler, D.M. (2004) Turbidimetry and nephelometry. In Townshend, A. (Ed.), Encyclopedia of Analytical Science. Second Edition. London: Academic Press. Pp 343-351.

Mayouf, J.A. (2013). Determination of ammonia, nitrate and nitrite concentrations in sea water samples mixed with waste water in Misurata, Libya. ARPN Journal of Science and Technology, 2(10): 1005-1008.

Morton, B. \& Blackmore, G. (2001). South China Sea. Marine Pollution Bulletin, 42(12): 12361263.

Patil, P.N., Sawant, D.V. \& Deshmukh, R.N. (2012). Physico-chemical parameters for testing of water - A review. International Journal of Environmental Sciences, 3(3): 1194-1207.

Redfield, A. (1958). The biological control of chemical factors in environment. American Scientist, 46: 205-221.

Schlosser, C., Klar, J.K., Wake, B.D., Snow, J.T., Honey, D.J., Woodward, E.M.S., Lohan, M.C., Achterberg, E.P. \& Moore, C.M. (2014). Seasonal ITCZ migration dynamically controls the location of the (sub) tropical Atlantic biogeochemical divide. PNAS, 111(4): 14381442.

Shazili, N.A.M., Yunus, K., Ahmad, A.S., Abdullah, N. \& Rashid, M.K.A. (2006). Heavy metal pollution status in the Malaysian aquatic environment. Aquatic Ecosystem Health and Management, 9(2): 137- 145.

Sigman, D.M. \& Hain, M.P. (2012). The biological productivity of the ocean. Nature, 3(6): 1-16.

Sundarambal, P., Balasubramanian, R., Tkalich, P. \& He, J. (2010). Impact of biomass burning on ocean water quality in Southeast Asia through atmospheric deposition: field observations. Atmospheric Chemistry and Physics, 10: 1132311336. 
Tan, C.K., Mansor, S., Ibrahim, H.M. \& Rashid, A. (2002). Studies of sea surface temperature and chlorophyll- $a$ variations in East Coast of Peninsular Malaysia. Pertanika Journal of Science and Technology, 10(1): 13- 24.

Teh, L. \& Teh, L. (2014). Reconstructing the marine fisheries catch of Peninsular Malaysia, Sarawak and Sabah, 1950-2010. Fisheries Centre, University of British Columbia, Vancouver, Canada.

Velsamy, G., Manoharan, S. \& Ganesan, S. (2013). Analysis of physico-chemical variations in sea water samples Uppanar Estuary, Cuddalore, Tamilnadu, India. International Journal of Research in Biological Sciences, 3(2): 80-83.
Wang, B., Wang, X. \& Zhan, R. (2003). Nutrient conditions in the Yellow Sea and the East China Sea. Estuarine, Coastal and Shelf Science, 58: 127-136.

Witter, A., Teh, L., Yin, X., Cheung, W.W.L. \& Sumaila, R. (2015). Taking stock and projecting the future of South China Sea fisheries. Fisheries Centre, University of British Columbia, Vancouver, Canada.

Yap, C.K., Chee, M.W., Shamarina, S., Edward, F.B., Chew, W. \& Tan, S.G. (2011). Assessment of surface water quality in the Malaysian Coastal Waters by using Multivariate Analyses. Sains Malaysiana, 40(10): 1053-1064. 